\author{
Казнох Ірина Богданівна, \\ аспірантка кафедри музикознавства \\ та хорового мистецтва \\ Львівського національного університету \\ ім. І. Франка \\ ORCID 0000-0003-0080-6349 \\ irynazvir@gmail.com
}

\title{
МУЗИЧНО-ВІРШОВА ОРГАНІЗАЦІЯ ПРАЗНИКА ВОЗНЕСІННЯ ГОСПОДНЬОГО (на матеріалі Любачівського Ірмологіона 1674 року $^{1}$ )
}

Мета роботи: виявити репертуар празника Вознесіння Господнього та простудіювати аналітичний комплекс співдії лінгвістичного й музикологічного інструментарію з Любачівського Ірмологіона 1674 року. Методологія дослідження полягає у контекстуально-аналітичному методі з використанням таких дисциплін як: історична палеографія, музична медієвістика, філологія та богословія канонічного тексту, що разом у поєднанні розкривають музичне мистецтво давнього ірмолойного репертуару. Наукова новизна визначає пріоритет комплексного осмислення піснеспівів празника Вознесіння Господнього, що вперше виявляє музичнориторичні фігури і тропи у канонічних текстах та співдію богословського змісту і музично-поетичної композиції. Висновки. Формотворча особливість музично-віршової організації піснеспівів празника Вознесіння Господнього структурується на варіативній метричній організації з розспівним мелосом мажорного і мінорного нахилу. Мелодичні поспівки викладені за принципом повторності у гласовій системі, що стилістично підтримує закладені риторичні фігури і тропи у канонічному тексті.

Ключові слова: празник, Вознесіння Господнє, стихира, «Нідр Отческих», «Родился єси», світильний.

Казнох Ирина Богдановна, аспирантка кафедры музыковедения и хорового искусства Львовского Национального университета им. И. Франка

Музыкально-стихотворная организация празника Вознесения Господня (На материале Любачивского Ирмологиона 1674)

Цель работы: выявить репертуар праздника Вознесения Господня и проштудировать аналитический комплекс содействия лингвистического и музикологичного инструментария с Любачевского Ирмологиона 1674 года. Методология исследования заключается в контекстуально-аналитическом методе с использованием таких дисциплин как: историческая палеография, музыкальная медиевистика, филология и богословия канонического текста, вместе в сочетании раскрывают музыкальное искусство древнего ирмолойного репертуара. Научная новизна определяет приоритет комплексного осмысления песнопений праздника Вознесения Господня, впервые проявляет музыкально-риторические фигуры и тропы в канонических текстах и содействует богословским содержанием и музыкально-поэтической композицей. Выводы. Формообразующих особенность музыкально-стихотворной организации песнопений праздника Вознесения Господня структурируется на вариативной метрической организации с розспивним мелосом мажорного и минорного наклона. Мелодические попевки изложены по принципу повторности в гласовой системе, стилистически поддерживает заложенные риторические фигуры и тропы в каноническом тексте.

Ключевые слова: праздник, Вознесение Господня, стихира, «Нідр Отческих», «Родился єси», светилен.

Kaznokh Iryna, post-graduate student of the Department of Musicology and Choral Arts of Ivan Franko Lviv National University

Musical and poetic composition the feast of the Ascension of the Lord (on the material of Liubachiv Irmologion, 1674)

The purpose of the article is to discover the repertoire of the feast of the Ascension of the Lord and study the analytical complex of the linguistic and musical language of Lubomachi Irmologion, 1674. The methodology of the research consists in the contextual-analytical method with the use of such disciplines as: historical paleography, musical mediavitics, philology and theology of the canonical text, which in combination reveals the musical art of the old irmological repertoire. Scientific novelty determines the priority of comprehensive comprehension of chants of the feast of the Ascension of the Lord, which for the first time reveals musical and rhetorical figures and tracks in canonical texts and co-produces theological content and musical and poetic composition. Conclusions. The formative feature of the musical and poetic composition of the chants of the feast of the Ascension of the Lord is structured on a variable metric organization with chanting melody of major and minor tilt. The melodic tunes are based on the principle of repetition in the tone system, which stylistically supports the laid-back rhetorical figures and tracks in the canonical text.

Key words: feast, Ascension of the Lord, stichera, " The womb of the Lord", "Born You", light.

(C) Казнох I. Б., 2019 
Актуальність теми дослідження. Особливе місце у музичній культурі України займає давня практика церковного співу, представлена великим репертуаром візантійської гимнографії. Сакральне літургійне мистецтво поєднює в собі два тотожних поняття в яких виокремлені вербальна та музично-пісенна складова: гимнографія та монодія, що втілені глибокими богословськими ідеями відомими візантійськими гимнографами та отцями. Щоденний ритм добового кола богослужінь засвоював, розвивав та розповсюджував на теренах України найкращі зразки візантійської релігійномистецької спадщини. У цьому контексті чільне місце у дослідженні займають піснеспіви одного із найбільших господських свят - Вознесіння Господнє, що представляє гимнографічну творчість Києво-Руської держави не лише як літургійну традицію, а як осередок давньої музичної культури.

Аналіз останніх досліджень і публікацій. Сакральне мистецтво ранньомодерної доби віддавна цікавить дослідників різного напрямку студіювання ірмолойного репертуару, зокрема такі сучасні дослідники як Юрій Ясіновський, Олександра Цалай-Якименко, Лідія Корній, Ірина Чижик, Олена Шевчук, Ольга Путятицька, Наталія Сиротинська, Марія Качмар, Тетяна Тесля, Наталія Юсипів та ін. вже чимало відкрили духовних надбань українського сакрального музичного мистецтва, проте залишається ще немало питань дослідницького характеру, зокрема до піснеспівів празника Вознесіння Господнього не зверталися.

Мета дослідження полягає, щоб виокремити репертуар празника Вознесіння Господнього 3 Любачівського Ірмологіона 1674 року та простудіювати аналітичний комплекс співдії лінгвістичного й музикологічного інструментарію у семантико-символічному полі.

Виклад основного матеріалу. Серед найбільших двунадесятих празників церковного року $є$ свято Вознесіння Господнього, яке відзначають на сороковий день після Великодня. У цей день закінчується перебування Воскреслого Спасителя на землі. Про події свята описано у всіх чотирьох Євангеліях. Празник Вознесіння Господнього є наступним величним святом після Воскресіння Христового, тексти його нагадують про шлях до вічного життя, який відкрив нам Христос.

У текстах богослужінь празника Вознесіння Господнього висвітлюється одночасно радісний, прославний і сумний характер, оскільки учні Христові ще 40 днів після Світлого Воскресіння переживали велику радість перебування з Учителем, та коли Господь возносився на небо, апостоли відчували смуток прощаючись із Христом.

Піснеспіви празника Вознесіння Господнього давньої ірмолойної традиції знаходяться в Каталозі Ю. Ясіновського «Українські та білоруські Ірмолої 16-18 ст.» [7]. Серед них $є 15$ стихир (із них 2 болгарського напіву), 13 ірмосів, 1 канон грецького напіву у Санкт-Петербурзькому Ірмолої 1752 p. $^{2}$ та 1 канон записаний без нот в Лежайському Ірмологіоні 1680-1681 pp. ${ }^{3}$, а також 1 світилен у Любачівському Ірмологіоні, який у Каталозі не зафіксований, проте є у наявності. Простудіювавши численні Ірмолої, Ю. Ясіновський зазначає: «Праця над ірмолоями як пам'ятками рукописної книжності потребує вміння читати і розуміти давнє письмо, розрізняти почерки, ідентифікувати стиль писарів, виявляти спільні риси в орфографії та графіці певної творчої школи чи мовно-півчого діалекту» $[6,211]$. Тож аналіз монодійного репертуару потребує використання методології таких дисциплін як: історична палеографія, музична медієвістика, філологія а також богословія канонічного тексту.

Для нашого дослідження ми обрали стихири празника Вознесіння «Нідр Отческих» та «Родился єси», які виконуються на вечірні та світилен утрені, що співається після канону. Вони написані у змішаній фактурі, в якій поєднуються три типи викладу: силабічний, мелізматичний та розспівний $[5,71]$. Метро-ритмічна структура піснеспівів укладена у вільному розмірі, а метричну будову піснеспівів визначає текст. О. Цалай-Якименко таку метро-ритмічну структуру піснеспіву називає «вільною грою» $[5,84]$. Метричний простір піснеспівів визначає половинна нота, яка служить часовим відліком. В межах певної ритмічної структури мелодичного рядка відбувається метрична варіантність, повторність, звуження або розширення.

Ладотональність піснеспівів розгортається у звуковому колі бінарної ладотональності (терцової та паралельно перемінної). Так, у стихирі «Нідр Отческих» і у світильному домінує мажорний нахил, а в стихирі «Родился єси» - мінорний. Мелодичні звороти піснеспівів утворені на основі оспівування стійких звуків. Мелодика виглядає хвилеподібно терцових ланок з чергуванням висхідного та низхідного руху. Тематику мелодики задає початкова поспівка, яку О. Цалай-Якименко ще називає «початкова ладова модель» [5, 62], що простежується упродовж твору.

Для детального аналізу співдії поетичного тексту з мелодикою виписуємо окремо тексти стихир та світильного, а також музичний матеріал, поділивши їх на фрази. О. Цалай-Якименко вказує, що «саме поділ тексту на синтактичні стопи задає первинну форму і для розчленування напіву 
на метро-ритмічні групи, цілості, які відповідають кожній стопі» [5, 69]. Отож, перша стихира у вечірньому богослужінні, яка виконується на Господи возвах, $\epsilon$ «Нідр Отческих»:

Нідр Отчески не отлучся сладкій Ісусе,

і со земними яко человік поживе,

днесь от гори Слеонскія вознеслся єси во славі,

і падшеє єстество наше милостинно вознесл,

Со Отиу посладил єси,

тімже небесні і безплотих чинове, чудеси удивляющеся,

ужасяхуся, страхом, і трепетом удержими,

Твоє чловеколюбіє величаху.

С ним же і ми земнії єже к нам твоє сохожденіє,

і єже от нас вознесеніє, Благодаряще,

молимся, глаголюще:

ученики, і рождиую тя Богородии,

радости безчисления ісполниви во твоє вознесеніє,

і нас сподоби ізбраних твоӥх, радости молитвами їх,

великія ради твоєя милости.

У стихирі висвітлюється момент вознесіння Ісуса Христа на землі на небеса і символіка цієї події. Поетичний текст стихири можемо поділити на 3 частини та позначити А, A1, A2. В цілому сюжет стихири написаний у риторичній фігурі клімакс (грец. озн. - «драбина» - фігура додавання). Поетичні фрази розташовані 3 поступовим наростанням їх смислової та емоційної ваги, що окреслюється логічним вступом, розробковим навантаженням, яке досягає кульмінаційного моменту та розв'язується у завершальній фразі стихири. Символічним поєднанням в обох частинах $\epsilon$ акцентуванння прослави Бога-чоловіколюбця. У першій фразі представлено Ісуса як Бога-людину, який є Господом, але жив на землі людським життям: «Нідр Отческих не отлучся сладкій Ісусе, $i$ со земними яко человік поживе». У другій - ангели дивувалися великому чудові та величали Господнє чоловіколюбство: «Твоє чловеколюбіє величаху». Також емоційний та наростаючий зв'язок у поетичному тексті між частинами А та A1 створюється завдяки риторичній фігурі гіпозевгмі (від грец. озн. «зв'язок, з'єднання, ярмо») у слові глаголюще, що вимагає продовження до третьої частини. В останній частині зображена безмежна padicmb, якою наповнилися учні та Богородиця із Вознесінням Ісуса. Ця фраза стихири закликає нас сповнитися такою ж радістю та бути серед Христових вибраних, як його учні: «і нас сподоби ізбраних твойх, радости молитвами їх».

У першій частині стихири спостерігається парадоксальне поєднання смислового значення слів у фразах Нідр Отческих, сладкий Ісусе та падшеє єстество наше милостинно вознесл. Таке незвичне поєднання слів розкриває сутність прихованого змісту та створює асоціації у семантичному полі. Узгодження метафоричних висловів розгортається у внутрішній сюжет стихири. Така риторична фігура поетичної мови називається оксюморон (грец. озн. - «нісенітниця»), або під тим же значенням ще розуміють троп, що називається алегорія (грец. озн. - «інша назва»). Цей троп заснований на алегоричному тлумаченні будь-якого образу, предмета чи особи, в якій головна фраза показує одне, але під ним мається на увазі інше. Тобто алегоричний троп висловлює припущення, здогади, завдяки яким у поетичній мові одне озвучується, проте розуміється інше значення. Завдяки такому метафоричному поєднанню у тексті слів з прямим і переносним значенням збагачується художня уява, що надає сприйняттю емоційного забарвлення.

Прочитавши стихиру, можемо зауважити зіставлення слів, які подібно звучать, проте різні за значенням. Гра звуків представлена у словах вознісся, возсів та вознесіння. Така фігура, заснована на грі звучання і значення слів, називається парономазія (грец. озн. - «гра близькими звуками»). Вживання i зіставлення таких слів надають строфі неповторного мовного звучання та афористичності.

Проаналізувавши текст стихири та поділивши його на смислові синтагми, визначаємо музичні фрази (поспівки) у піснеспіві, що утворюють музичну форму завдяки синкретичній метриці. Музичну форму піснеспіву «Нідр Отческих» можна визначити як тричастинність, що підтримується каденційними зворотами та послідовністю викладу змісту. Також як в тексті, так і в музичному матеріалі літерами можемо позначити A A1 A2, оскільки експозиційні ладові мотиви повторюються в розробковій та завершальній частині. У стихирі домінує силабічний тип викладу, у кульмінаційному 
місці у слові сподобити спостерігається розспівна фактура, в якій силабіка тексту розтягується і на один склад тексту припадає 8 долей.

Відома дослідниця О. Цалай-Якименко, проаналізувавши численні піснеспіви з Імологіонів, зазначає, що «у напівах Ірмолоя бачимо чітку трифазність ладового становлення музичної форми, яка виразно членується на основні розділи - експозицію «теми» (ладової іiі формули), серединний розвиток і замикання» $[5,57]$. Тому трифазність ладового розгортання мелодики, яку простудіювала О. Цалай-Якименко, тобто сприйманням зором, проявляється у стихирі «Нідр Отческих», в якій спостерігаємо експозиційну тему в розробці четвертого рядка у слові $i$ падщеє та останнього - у слові великія. Серединна частина містить нову розробкову мінорну формулу, яка проявляється словами єстество, i трепетом, к нам Твоє, $і$ єже, ученики, Богородииу та ради Твоєя. Ладовий простір піснеспіву окреслений в межах $\mathrm{C}-\mathrm{a}$.

Формотворча метричність стихири «Нідр Отческих» складається із 15 лаконічних фраз, які написані у чотирьох типах ритмічної структури музично-віршового рядка: метрична варіантність, повторність, звуження або розширення. Межі метричної будови фраз піснеспіву окреслені в межах 9 - 32-дольних розмірів. Звужена метрична організація (9-дольна) спостерігається в 11 фразі в словах молимся глаголюще, а розширена (32-дольна) представлена в кульмінаційному місці в словах $i$ нас сподоби ізбраних Твоїх, радости молитвами їх. Метричну повторність бачимо у 17-дольному розмірі в другій і в четвертій фразі, 16-дольний - у десятій і в п’ятнадцятій та 14-дольний - у восьмій i дванадцятій фразі.

Експозиційна строфа стихири «Нідр Отческих» написана у формі періоду наскрізного розвитку. Кожне речення починається із розспівування першого слова у фразі, що триває упродовж першої частини, і початковий мотив звучить протягом цілого твору.

Поетичне значення слів підтримується у мелодиці. Певні мелодичні формули підкреслюють основний зміст, закладений у стихирі, та емоційно його підсилюють. У третьому рядку експозиції знаходимо поспівку, що передає вознесіння Господнє у фразі вознеслся єси во славі. Коли Ісус Христос возносився із землі на небо, то відбувався процес піднімання, тому в мелодичному матеріалі мелодія рухається знизу вверх, досягаючи найвищої ноти $a$, і затримується цілими тривалостями у слові славі, щоб відобразити таким чином велич Христову та завершити головну думку експозиційного матеріалу.

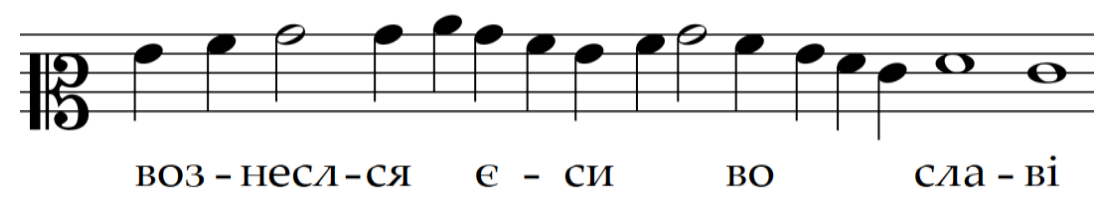

\section{Приклад 1 поспівка стихири «Нідр Отческих»}

Також фразу чудеси удивляющеся у розробці шостого рядка мелург передає за допомогою синкоп у складі «ще», щоб передати емоційний, трепетний стан небесних хорів, які дивилися на Христове вознесіння.

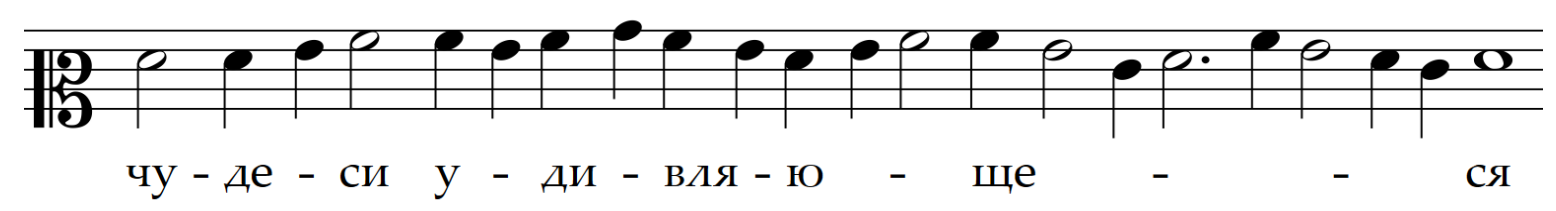

\section{Приклад 2 поспівка стихири «Нідр Отческих»}

Слова $i$ соземними, чловеколюбіє, ми земнії та фразу, яка стосується христових учнів i Богородиці, що жили на землі молитвами $\ddot{x}$, мелург відтворює однаковими мотивами із розспівуванням кожного складу слова четвертними, групуючи їх по два та завершуючи фразу половинкою і цілою нотою. Мотив починається терцовим тоном «е», що відображає серединний простір між землею та небом. Адже ангели на небі разом із земними людьми величали Христове чоловіколюбство у день Вознесіння, тому Христові вибранці сподобляють нас сьогодні своїми молитвами. 

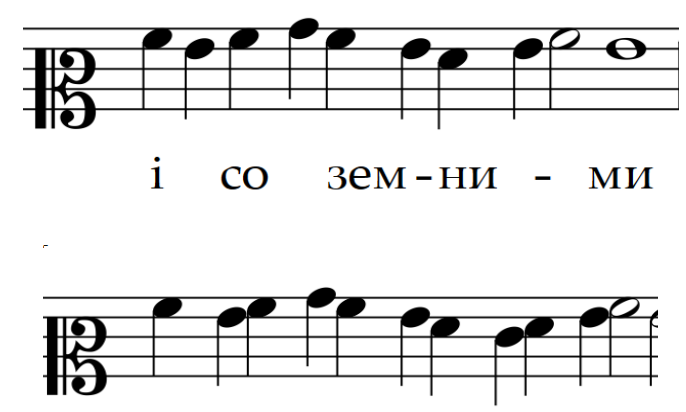

чло ве - ко- Яю-бі -

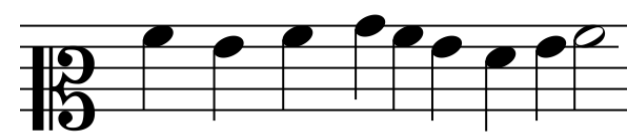

ми зем - ні - $\ddot{1}$

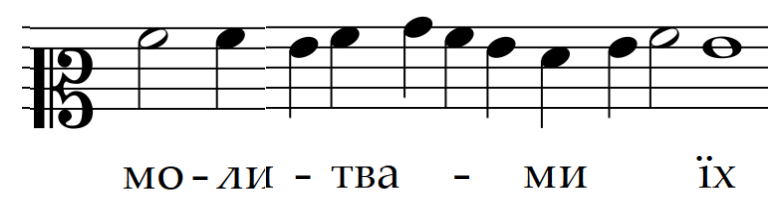

Приклад 3 поспівки стихири «Нідр Отческих»

Загалом музична мова стихири викладена у розспівній фактурі, проте у дев’ятій фразі на слові с ними же є скачок на кварту. Такий ритмічний малюнок дуже логічний, оскільки відображає та прирівнює прославу Бога земними людьми до ангельської.

Наступний піснеспів «Родился єси» відноситься до циклу стихир на стиховні вечірнього богослужіння:

Родился єси яко сам восхотіл єси,

явился єси яко сам ізволил єси:

пострадави плотію Боже наш

і мертвих воскресил єси, поправи смерть;

вознеслся єси, всяческая ісполняя;

і послал єси нам Дух Божествений,

єже воспівати, і славити

Твоє Божество.

У сюжеті стихири викладено основні події із життя Ісуса Христа від народження до Зіслання Святого Духа, а саме: Різдво, Богоявління, Пасха, Вознесіння та П'ятидесятниця. Таке емоційне та смислове навантаження у фразах створюється завдяки риторичній фігурі клімакс. Також наявна фігура додавання - полісіндетон (від грец. озн. - «багатосполучниковість»), що складається 3 багаторазового повтору частки $\epsilon с и$. Це створює певний стилістичний ефект у стихирі: сповільнюється темп мови, значнішим стає кожне із слів, які з'єднані часткою, та спонукає читача до узагальнення i сприйняття ряду деталей, як цілісного образу. Не менш важливе навантаження у синтаксичному паралелелізмі надає збіг граматичних форм у закінченнях слів родился, явился та вознеслся, що створює ефект римування строфи. Така фігура називається гомеотелевтон (грец. озн. - «має те ж закінчення»). Ці стилістичні вислови передають торжественість звучання стихири.

Стихира написана в музичній формі наскрізної імітації, у якій трапляються подібні мотиви, проте мелодика постійно розгортається і видозмінюється залежно від змісту тексту. Музичновіршова організація стихири «Родился єси» складається із сімох логічних фраз, які можна визначити за допомогою тексту, завершальних зворотів у метричній групі - ціла нота та знаки якості. У стихирі домінує силабічний тип викладу, у кульмінаційному місці в слові славити спостерігається розспівна фактура, в якій силабіка тексту розтягається, і на один склад тексту припадає 9 долей. Метрична структура піснеспіву виглядає так: 1 фраза - 14-дольна; 2 - 17-дольна; 3 - 18-дольна; 4 - 17-дольна; 5 
- 16-дольна; 6 - 15-дольна; 7 - 31-дольна. Таким чином, ми бачимо варіативну метричну будову в межах 14 - 18-долей і розширену останню фразу в кульмінаційному місці - 31-дольний розмір.

У піснеспіві в основному спостерігається ладотональність a-moll, проте експозиційна строфа стихири мажорного нахилу, яка розпочинається із нестійкого звука d i переходить в $\mathrm{C}$-dur та розгортає свою вершину на третьому ступені мажорної тональності і закінчується низхідним рухом у паралельну тональність a-moll.

Загалом мелодика стихири розспівного характеру, мелізматичний розспів викладений у фразах плотію Боже наш, поправи смерть, всяческая ісполняя, послал єси нам Дух, славити Твоє Божество. Діапазон піснеспіву утримується в межах однієї октави g-f. Мелос рухається плавно, хвилеподібно. Логічний скачок на кварту спостерігаємо у п'ятій фразі на слові вознеселся. Мелург, творячи піснеспів за допомогою кварти і затримавши іiі цілою нотою, хотів передати таким чином момент піднімання вгору, щоб відобразити Вознесіння Господа. Тому мелодика порушує свою статичну розспівність.

Велику увагу в кожному рядку привертають ладові й ритмічні каданси, які у перших шістьох рядках закінчуються однаково - цілою нотою. В останньому рядку спостерігаємо кульмінацію у слові славити, що проявляється розлогою мелізматикою, висотністю звуку та ритмічним малюнком, який вирізняється з-поміж усіх поспівок у творі.

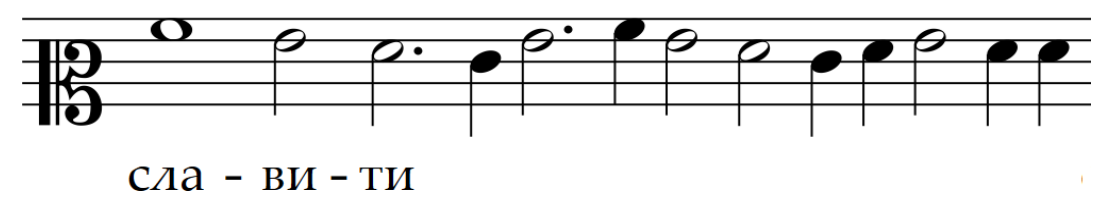

Приклад 4 поспівка стихири «Родился єси»

Наступний піснеспів, який зафіксований у Любачівському Ірмологіоні на Вознесіння Господнє, є світилен в якому оспівуємо «Бога як Світло і Подавця світла». Світилен - єдиний піснеспів, що не має гласової приналежності, а є самогласним. За своєю структурою це короткий піснеспів, у якому розкрито основну подію празника:

Учеником зрящим тя, вознеслся єси Христе

Отиу сопрестолствуя,

Ангели предтекуще зов'яху,

возміте, врата возміте,

Цар бо возіде,

ко началному світу слави.

Якщо у стихирах свята Вознесіння Господнього згадуються події ще із життя Ісуса Христа, то у світильному висвітлено сам момент вознесіння Господа до Небесного Царства. У перших чотирьох фразах представлено головних героїв, що були присутні в часі вознесіння - апостоли, які споглядали Господне диво, та ангели, що приготовляли небесний престол, на який сяде разом з Отцем Його Син. В останніх фразах світильного викладено роз'яснення та завершення головної мети празника Вознесіння словами Цар бо возіде, ко началному світу слави. Такий особливий зміст останньої фрази світильного підкреслюється використанням поетичної фігурі ексергасія (грец. озн. - «розробка, роз'яснення, завершення»). Суть цієї фігури полягає у викладенні та повторенні однієї думки, що стосується певної особи. Тому у світильному ми бачимо два шляхи розвитку тієї ж події, що відбувалася за участю Ісуса Христа. У першій дії апостоли дивилися на вознесіння Учителя, а у другій - ангели у той же час відкривали Царські брами.

Музична форма світильного має риси одночастинності, що складається 3 трьох речень. Експозиційна строфа кожного речення однакова, а друга частина видозмінена. Хоча друга частина речень $\epsilon$ змінною, проте мелодика має логічне розгортання, що завершується на основному звуці $c$ цілою нотою. Мелодика світильного розспівного характеру в межах однієї октави а-a.

Метрична структура світильного базується чотиридольним розміром, який можна чітко розділити тактовими рисками, проте поетичні фрази світильного організовують групову метричність нот і музично-віршова організація вибудовує варіативну і повторну метричну будову піснеспіву в межах 10 - 15 долей, зокрема, перша фраза - 10-дольна; 2 - 10-дольна; 3 - 11-дольна; 4 - 15-дольна; 5 - 12-дольна; 6 - 10-дольна; 7 - 13-дольна. У наведених сімох фраз світильного ми бачимо 
повторювальну метричну будову в першій, другій і в шостій фразі та варіативну в третій, четвертій, п’ятій і сьомій.

Наукова новизна визначає пріоритет комплексного осмислення піснеспівів празника Вознесіння Господнього, що вперше у семантико-символічному полі визначає вербальну складову півчих сакральних текстів, базованої на риторичних засадах наділених богословською мудрістю, що спільно з мелодикою визначають зміст і форму творів.

Висновки. Проаналізувавши три піснеспіви празника Вознесіння Господнього, ми побачили що формотворча особливість музично-віршових структур базується на варіативній метричній організації. В основному спостерігається розспівний тип викладу, проте трапляється логічне ритмічне відхилення, що підтримується текстом. Спостерігаємо принцип повторності мелодики у гласовій системі. Поетичний текст викладений стилістичними фігурами і тропами, які підкреслюють зміст та значення слова. Кожна фігура є частиною своєрідної «гри», метою якої $є$ привертання уваги, тож часто використовуються риторичні фігури. В цьому контексті піснеспіви празника Вознесіння Господнього $\epsilon$ виразним свідченням високої мистецької майстерності давнього монодійного репертуару. Запропоновані висновки відкривають теми для подальшого студіювання гимнографії празника Вознесіння Господнього у сакральному обряді. Робота дає можливість дослідити українську культуру у семантико-християнському вимірі. Отримані результати можуть використовуватися в процесі викладання низки навчальних дисциплін, зокрема музичного, філологічного та богословського напрямку.

\section{Примітки}

${ }^{1}$ Рукопис переписаний Павлом Смеречанським у м. Любачів (тепер - Польща). Сьогодні зберігається у Львівському Державному Історичному музеї, Рук. 103.

${ }^{2}$ Ірмологіон записаний Гаврилом Головним, придворний півчий, м. Санк-Петербург. Зараз зберігається у Києві у Центральній Науковій Бібліотеці ім. Вернадського НАН України, Інститут рукописів, ф. ДА ІІ. 351.

${ }^{3}$ Ірмологіон записаний Василем Скалацьким, дидаскал, у м. Лежайськ. Зараз зберігається у Львівській Науковій Бібліотеці ім. В. Стефаника НАН України, ф. НД 103.

\section{Лimepamypa} 272-287.

1. Герасимова-Персидська Н. Слово і музика в XVII ст. К. : Українське літературне бароко, 1987. С.

2. Сиротинська Н. Перло Многоцінне: музично-поетичний світ богородичної гимнографії : Монографія. Львів : Видавець Тетюк Т. В., 2014. 336 с.

3. Сиротинська Н. І. Риторичні прийоми у структурі візантійської гимнографії та української сакральної монодії. Наукові збірки Львівської національної музичної академії імені М. В. Лисенка. 2017. № 40. C. $17-27$.

4. Сиротинська Н. Мелодико-поетичні паралелі у візантійській гимнографії та українській монодії. КА ОФ Католицького Університету, 2014. № 7. С.146-154.

5. Цалай-Якименко О. Київська школа музики XVII ст. Київ ; Львів ; Полтава : НTШ, 2002. 489 с.

6. Ясіновський Ю. Візантійська гимнографія i церковна монодія в українській рецепції Ранньомодерного часу : Монографія. - Львів : Ін-т українознав. ім. І. Крип'якевича, 2011. 467 с.

7. Ясіновський Ю. Українські та білоруські нотолінійні Ірмолої 16-18 століть: Кат. і кодиколог.палеограф. дослідж. Львів : Місіонер, 1996. - 624 с.

\section{References}

1. Gherasymova-Persydsjka N. (1987). Word and music in the seventeenth century. Kyiv: Ukrajinsjke literaturne baroko [in Ukrainian].

2. Syrotynsjka N. (2014). Pearl of high value: the musical and poetic world of the mother of God's hymnography. Monoghrafija. Ljviv : Vydavecj Tetjuk T. V. [in Ukrainian].

3. Syrotynsjka N. I. (2017). Rhetorical receptions in the structure of the Byzantine hymnography and Ukrainian sacred monody. Naukovi zbirky Ljvivsjkoji nacionaljnoji muzychnoji akademiji imeni M. V. Lysenka, 40, 17- 27 [in Ukrainian]

4. Syrotynsjka N. (2014). Melodious poetic parallels in the Byzantine hymnography and the Ukrainian monody. Naukovyj zbirnyk z istoriji cerkovnoji monodiji ta ghymnoghrafiji, 7, 146-154 [in Ukrainian] Ukrainian]

5. Calaj-Jakymenko O. (2002). Kiev school of music of the XVII century.. Kyjiv ; Ljviv ; Poltava : NTSh. [in

6. Jasinovsjkyj Ju. (2011). Byzantine hymnography and church monody in the Ukrainian Reception of the Early Modern Time: monoghrafija. Ljviv : In-t ukrajinoznav. im. I. Kryp'jakevycha. [in Ukrainian]

7. Jasynovsjkyj Ju. (1996). Ukrainian and Byelorussian noolinistic Irmolos of the 16th-18th centuries: Kat. i kodykologh.-paleoghraf. doslidzh. Ljviv : Misioner. [in Ukrainian] 